\title{
Lipid metabolism in genetic models of obesity
}

\section{By D. A. York, Department of Physiology and Biochemistry, The University of Southampton, Southampton $\mathrm{SO}_{9}{ }_{3} \mathrm{TU}$}

Over the last decade, animal models of obesity have been used extensively to study the mechanism underlying the increased deposition of fat and the changes in metabolism resulting from the increased adiposity. Two genetic models of obesity have received particular attention; the obese-hyperglycaemic (obob) mouse and the Zucker 'fatty' (fafa) rat, since in both species the obesity is inherited as a singlegene, homozygous recessive trait and presumably represents a defect in a single protein. These genetic forms of obesity may provide good models for obesity in man, particularly obesity of the juvenile-onset form, and an understanding of their metabolism may benefit our knowledge of the human obesities. Although a vast literature has described metabolic, endocrine, morphological and behavioural changes in these obese rodents (Bray \& York, 1971), this review will concentrate on more recent studies of their lipid metabolism.

\section{Characteristics of obob mice and fafa rats}

Both the fafa rat and obob mouse are hyperphagic when allowed food ad lib. Insulin levels are increased and insulin resistance is clear in both adipose tissue and muscle (Stauffacher \& Renold, 1969; York \& Bray, 1973a), although only the obob mouse is hyperglycaemic.

The adipocyte population of lean rats has been found by Hirsch and his colleagues (Knittle \& Hirsch, 1968) to be controlled by energy intake in the first few weeks of life to reach a fixed adult number by 16 weeks of age. In contrast, new fat cells were continually formed in certain fat depots of the fafa rat and obob mouse (Johnson, Zucker, Cruce \& Hirsch, I971; Johnson \& Hirsch, 1972). Early nutritional deprivation does reduce fat-cell number in the fafa rat, but the total cell population still remains considerably increased when compared to overfed, lean control rats (Johnson, Stern, Greenwood, Zucker \& Hirsch, 1973). Thus, although nutritional status influences the development of new fat cells in the obese rat, the homozygous genotype is always expressed as a hyperplasia and hypertrophy of the adipose tissue. Similarly, fat-cell number of obob mice is also increased (Johnson \& Hirsch, 1972). However, the obesity associated with damage to the ventromedial satiety centre in rats or mice is not accompanied by hyperplasia of the fat cells. In this instance the extra triglyceride (TG) is stored by hypertrophy of the fat cells (Hirsch \& Han, 1969). Unfortunately, starvation succeeds only in reducing fat-cell size and has no effect on cell number (Hirsch \& Han, 1969). 


\section{Circulating lipids}

The serum of fafa rats is often lactescent, reflecting the very high levels of circulating TG and cholesterol (Barry \& Bray, 1969). Although some of this hyperlipidaemia is of intestinal origin, recent studies have suggested that the liver secretes increased amounts of lipoprotein (Schonfeld \& Pfleger, 1971). All classes of lipoprotein are increased in the blood of fafa rats, but the increment in very-lowdensity lipoprotein (VLDL) is particularly large and their TG content is also increased (Schonfeld, Felski \& Howald, 1974), another pointer to the involvement of the liver in the hyperlipidaemia. Likewise, obob mice are hyperlipidaemic, but in this instance the increase is mainly cholesterol (Salmon \& Hems, I973). Free fatty acid (FFA) concentrations are increased in fafa serum, but may be high or normal in obob mice (Steinmetz, Lowry \& Yen, 1969; Zucker, 1972; Salmon \& Hems, 1973).

\section{Lipogenesis}

The high levels of circulating VLDL during starvation, together with the persistence of hypertriglyceridaemia when they are pair-fed either to lean or to hypothalamic-obese rats, suggest that fafa rats have an increased capacity for the hepatic synthesis of TG (Barry \& Bray, 1969). Schonfeld \& Pfleger (197I) have recently confirmed this hypersecretion of VLDL using an isolated, perfused liver system and further showed that all the normal apolipoproteins were present and that no unique apolipoproteins appeared (Schonfeld et al. 1974).

The fatty acids (FA) used for glyceride synthesis could come either from endogenous synthesis in the liver or from the circulation. There is as yet no information to quantitate the contribution of these two sources, but the high levels of circulating FFA could obviously be a major component. However, preliminary observations (D. Bloxham \& D. A. York, unpublished results) have shown that FA synthesis from a variety of substrates is increased 3-4-fold in hepatocytes isolated from fafa rats compared to those from their lean controls. In both types of animal, glucose at physiological concentrations appears to be a poor substrate for FA synthesis, whereas lactate carbon is rapidly incorporated, a result which confirms observations from other laboratories (Clark, Bloxham, Holland \& Lardy, 1974; Clark, Rongstad \& Katz, 1974). The possibility that these changes result from the hyperinsulinaemia of these animals cannot be ruled out at this stage. However, Zucker \& Antoniades (1972) have reported that Zucker rats can be separated statistically at 2 weeks of age into two populations on the basis of total body fat, before there is an increase in circulating insulin concentration. These findings suggest that excess lipid deposition commences before the onset of hyperinsulinaemia.

The hypertriglyceridaemia of fafa rats reflects their inability to clear the circulating lipids at a rate sufficient to compensate for the increased production, despite an increase in the activity of adipose tissue lipoprotein lipase activity (de Gasquet \& Péquignot, 1974).

In rats and mice the adipocytes are responsible for the synthesis of a large proportion of the total FA. For this reason, and because of the simpler techniques 
involved, the adipose tissue has been a major focus for much of the research in obese rodents. Adipocytes from fafa rats synthesize FA at a rate which is 60 -fold greater than that for lean controls at 6 weeks of age (York \& Bray, 1973b). This increased rate of synthesis probably plays an important part in the development of the hypercellularity in later life. Although the lipogenic rate per cell is identical to that of lean controls by 18 weeks (York \& Bray, 1973a), this still represents an increased total capacity for FA synthesis, as adipocyte number is increased substantially by this age. FA esterification rates are very high, considerably greater even than those in hypothalamic obese rats. This does not appear to result from the appearance of unusual glycerol kinase (EC 2.7.1.30) activity in fafa fat cells but probably reflects the existence of an adequate supply of $S n$-glycero-3-phosphate in the presence of an increased supply of FA (Bray, Barry \& Mothon, 1970). There is no evidence that the concentration of $S n$-glycero-3-phosphate is rate-limiting for the incorporation of substrate into glyceride-FA.

Considerably more information has accumulated on lipogenesis in the obob mouse. In particular, studies of hepatic metabolism have been reported in a number of recent publications. Again, both adipocyte and hepatic synthesis of FA from a number of percursors are increased compared to both lean litter-mate and gold-thioglucose-obese controls (Christophe, Jeanrenaud, Mayer \& Renold, r96r; Loten, Rabinovitch \& Jeanrenaud, 1974), whereas lipogenesis in other tissues, e.g. skin, remains normal.

An increased activity of acetyl-CoA carboxylase (EC 6.4.1.2), consistent with this increased FA synthesis, has been shown in the liver and adipose tissue of obob mice (Nakanishi \& Numa, 1971; Christophe, Winand \& Furnell, 1972) and fafa rats (Takemoto, Ishikawa \& Iwatsuka, 1975). This is thought to reflect an increase both in the concentration of the enzyme and in its extent of aggregation. Other lipogenic enzymes, e.g. FA synthetase, ATP citrate lyase ( $E C$ 4. I.3.8), are similarly increased in activity (Kornacker \& Lowenstein, 1964; Chang, Seidman, Teebor \& Lane, 1967). It is improbable that the high rate of FA synthesis in these animals represents a total loss of normal control mechanisms as, for example, FA synthesis is inhibited by a reduction in serum insulin (Loten et al. 1974), by food restriction (Bates, Mayer \& Nauss, 1955) and by giving a high-fat diet (York, 1975). However, a loss of the allosteric control of phosphofructokinase ( $E C$ 2.7.1.1 I) by ATP and citrate has been demonstrated (Katyare \& Howland, 1974). The significance of this finding is not clear in the light of recent evidence that the liver is normally gluconeogenic (Clark, Bloxham et al. 1974). Is it possible that these obese livers display a net rate of glycolysis?

TG synthesis and secretion into the circulation as VLDL are also increased (Assimacopoulos-Jeannet, Singh, Le Marchand, Loten \& Jeanrenaud, I974; Rath, Hems \& Beloff-Chain, 1974). In this instance, circulating FFA have been shown to be a major substrate for TG synthesis. An increased rate of TG removal into the peripheral tissues for which an enhanced activity of lipoprotein lipase activity in adipose tissue and cardiac muscle is probably responsible, compensates for the overproduction of TG and the serum TG remains normal (Enser, 1972; de Gasquet \& Péquignot, 1974). Thus the rate of FA turnover in TG has been 
calculated to be increased in obob mice from 0.30 to $1.50 \mu \mathrm{mol} \mathrm{FA} / \mathrm{min}$ (Salmon \& Hems, r 973).

The hyperinsulinaemia of obob mice appears to be responsible in part at least for the enhanced TG turnover. FA synthesis in both liver and adipose tissue is insensitive to exogenous insulin, possibly because the rates are already approaching maximal. However, streptozotocin, which destroys the pancreatic $\beta$ cells, reduces FA synthesis towards control levels (Assimacopoulos-Jeannet et al. 1974). It also restores the ability of livers from obob mice to respond to exogenous long-chain FA. Using a perfused liver system, Assimacopoulos-Jeannet et al. (1974) have further shown that oleic acid stimulates TG secretion and ketone body formation by normal livers. No oleic acid effect could be demonstrated in livers of obob mice until the basal TG secretion rate was reduced by previous streptozotocin treatment.

Analysis of the FA composition of adipose tissue and liver TG in both obob mice and fafa rats indicate that the proportions of palmitoleic (16:I) and oleic (18:1) acids were increased and linoleic acid (I8:2) decreased (Christophe et al. 1961; Wahle, 1974). This probably reflects an increase in the microsomal 9-acylCoA-desaturase activity by insulin. This relative deficiency of linoleate might also contribute towards the induction of acetyl-CoA carboxylase and FA synthetase in these obese syndromes (Muto \& Gibson, 1970). However, since adiposity increases before the increase in circulating insulin and insulin resistance in both obob mice and fafa rats, it is unlikely that the hyperinsulinaemia is a primary cause of the initial increment in fat deposition (Zucker \& Antoniades, 1972; Joosten \& van der Kroon, 1974a).

A similar metabolic profile thus probably exists in the livers of both fafa rats and obob mice. The livers are confronted with the unusual situation of high insulin levels, an increased supply of FFA from the circulation and an increased supply of substrate from the diet. As a result FA synthesis is increased and TG production and secretion are maintained at near-maximal rates. Lipoprotein lipase activity of peripheral tissues is enhanced in an attempt to clear the excess TG. Over-all this leads to an increased turnover rate for FA in TG. It remains to be seen whether any of these changes represent a primary defect in liver metabolism.

\section{Lipolysis}

The lipolytic system of these adipocytes has been studied by many laboratories. The early literature (Marshall \& Engel, 1960; Steinmetz et al. 1969; Enser, 1972) suggested that adipocytes of obob mice were characterized by a reduced basal lipolysis and reduced sensitivity to the lipolytic hormones. However, these results were all expressed on a tissue weight or tissue nitrogen basis. If they are recalculated to be expressed as FFA or glycerol release per cell using the values for $\mathrm{N}$ content and cell number of Abraham (1973) it is clear that basal rate of lipolysis per cell is increased in fat cells of obob mice. This has been confirmed by recent observations in our laboratory (Table $\mathrm{I}$ ).

The metabolism of fat cells in vitro and its control by hormones is influenced by 
Table I. Adrenaline-stimulated glycerol release ( $\mu \mathrm{mol} / 10^{6}$ cells per $h$ ) from adipose tissue of lean and obese mice incubated in vitro"

(Mean values with their standard errors for six mice/group)

\begin{tabular}{ccccc} 
& \multicolumn{2}{c}{ Obese } \\
\cline { 2 - 3 } Adrenaline $(\mu \mathrm{g} / \mathrm{ml})$ & $\overbrace{\text { Mean }}^{\text {Lean }}$ & & SE \\
0 & 0.24 & 0.02 & 3.11 & 0.49 \\
0.1 & 0.71 & 0.10 & 2.09 & 0.15 \\
1.0 & 0.99 & 0.10 & 3.44 & 0.62 \\
10.0 & 1.16 & 0.05 & 5.75 & 0.66 \\
50.0 & 1.54 & 0.12 & 7.94 & 0.44
\end{tabular}

-From W. Otto \& D. A. York (unpublished results).

the composition of the diet, age, the state of growth of the animal and the cellular characteristics of the adipose tissue (Salans, Cushman, Horton, Danforth \& Sims, 1974). However, if all other parameters are constant, basal lipolysis increases with increasing size of the adipocyte and this is a possible explanation of the increased lipolysis under basal conditions of fat cells of obob mice. The mechanism underlying this relationship is not clear. However, when cyclic AMP concentration of obob adipose tissue (Enser, 1972) is recalculated on a fat-cell basis as previously outlined, the cyclic AMP concentration of these fat cells is clearly increased. Similarly the increased basal lipolysis of fafa rat adipose tissue has been shown to be related to fat cell size and to be accompanied by an increased level of cyclic AMP in the adipocytes under these conditions (Bray, Luong \& York, 1974). These changes, which appear to be secondary to the obesity, might result from an increase in adenylate cyclase $(E C$ 4.6.1.1) activity or a decrease in phosphodiesterase (EC 3.1.4.17) activity and an increase in the lipase concentration within the cell. As yet these aspects have not been studied satisfactorily.

The reported reduction in the response of adipocytes of obob mice and fafa rats to lipolytic hormones, particularly in older animals, must be interpreted in the light of this increased basal lipolysis. Thus, although adrenaline produces a smaller percentage stimulus of glycerol release in the obese adipocytes, the glycerol release per cell at a given dose of adrenaline is greater than in the lean controls (Table I and Bray $e$ t al. 1974). The situation is further confused by the increased rate of FFA re-esterification in the obese fat cells resulting from an increased availability of $\alpha$-glycerophosphate derived either from glycolysis (Bray et al. 1970) or through an enhanced glycerol kinase activity as has been suggested for obob mice (Treble \& Mayer, 1963). Indeed, Koschinsky, Gries \& Herberg (1971) have estimated that up to one-fifth of the glycerol released by lipase activity may be rephosphorylated by glycerol kinase. It is probable that this high glycerol kinase activity is a reflection of the hyperinsulinism.

Other evidence suggests that these animals do not have a defective lipolytic system. At 6 weeks of age fat cells from fafa rats show a normal percentage increment in glycerol release under the influence of adrenaline (York \& Bray, 
1973b). In vivo studies have shown that adrenaline increased circulating FFA concentration and glycerol normally in fafa rats (Zucker, 1972). Both obob mice and fafa rats withstand prolonged starvation (Zucker, 1967; Chlouverakis \& White, 1969).

Thus it appears likely that most, if not all, of the changes in lipolysis and hormone effects found in these obese syndromes may be a consequence of the expanding cell volume and number and of the hyperinsulinaemia. However, Tsuji $\&$ Meier (1970) have found that the isozyme pattern of lipolytic esterases shows some deletions in adipose tissue of obob mice. The significance of this finding is not clear. It appears therefore from esterification and lipolytic rates that the TG-FA cycle within the adipose cell turns over at an increased rate in these obese models. As fat-cell number is also increased this results in an increased supply of FFA and glycerol to the liver and other tissues. It has been suggested that FA re-esterification rate decreases with increasing fat-cell size in normal rats (Salans $e t$ al. 1974). Such a system, with the increasing lipolysis with fat-cell size, would allow the fat cell to limit the size to which it could grow. Unfortunately, there is insufficient information from these obese models to ascertain whether such a control still exists.

It has so far not proved possible to attribute the obesity to any enzyme, structural or regulatory protein in either of these models, or even to show conclusively that the defect is directly concerned with lipid metabolism. All obesities, with the possible exception of that due to high-fat diets, are accompanied by some extent of hyperinsulinaemia and insulin resistance and hyperphagia. As thyroid and reproductive defects have also been described in both the fafa rat and obob mouse (Bray \& York, 1971; Joosten \& van der Kroon, 1974b) some impairment of hypothalamic control has been suggested in both models. Alternatively, as the deposition of body protein is impaired in both obob mice and fafa rats (Bray, York \& Swerdloff, 1973; Pullar \& Webster, 1974; Bergen, Kaplan, Merkel \& Leveille, 1975), the obesity might be a secondary reflection of a defective protein synthetic or catabolic system.

\section{REFERENCES}

Abraham, R. (1973). Diabetologia 9, 303.

Assimacopoulos-Jeannet, F., Singh, A., Le Marchand, Y., Loten, E. \& Jeanirenaud, B. (1974). Diabetologia 10, 155.

Barry, W. \& Bray, G. (1969). Metabolism 18, 833 .

Bates, M., Mayer, J. \& Nauss, S. (1955). Am. $\mathcal{Y}$. Physiol. 180, 309.

Bergen, W., Kaplan, M., Merkel, R. \& Leveille, G. (1975). Am. f. clin. Nutr. 28, 157.

Bray, G., Barry, W. \& Mothon, S. (1970). Metabolism 19, 839.

Bray, G., Luong, D. \& York, D. (1974). In The Regulation of the Adipose Tissue Mass, p. II2 [J. Vague and J. Boyer, editors]. Amsterdam: Excerpta Medica.

Bray, G. \& York, D. (1971). Physiol. Rev. 51, 598.

Bray, G., York, D. \& Swerdloff, R. (1973). Metabolism 22, 435.

Chang, H., Seidman, J., Teebor, G. \& Lane, M. (1967). Biochem. biophys. Res. Commun. 28, 682 .

Chlouverakis, C. \& White, P. (1969). Metabolism 18, 998.

Christophe, J., Jeanrenaud, B., Mayer, J. \& Renold, A. (1961). F. biol. Chem. 236, 648.

Christophe, J., Winand, J. \& Furnell, J. (1972). Proc. gth int. Congr. Nutr., Mexico 1972, 1, 296. 
Clark, D., Rongstad, R. \& Katz, J. (1974). F. biol. Chem. 249, 2028.

Clark, M., Bloxham, D., Holland, P. \& Lardy, H. (1974). f. biol. Chem. 249, 279.

de Gasquet, P. \& Péquignot, E. (I974). In The Regulation of the Adipose Tissue Mass, p. 47 [J. Vague and J. Boyer, editors]. Amsterdam: Excerpta Medica.

Enser, M. (1972). Biochem. F. 129, 447.

Hirsch, J. \& Han, P. (1969). F. Lipid Res. 10, 77

Johnson, P. \& Hirsch, J. (1972). F. Lipid Res. 13, 2.

Johnson, P., Stern, J., Greenwood, M., Zucker, L. \& Hirsch, J. (1973). J. Nutr. 103, 738.

Johnson, P., Zucker, L., Cruce, J. \& Hirsch, J. (1971). F. Lipid Res. 12, 706.

Joosten, H. \& van der Kroon, P. (1974a). Metabolism 23, 59.

Joosten, H. \& van der Kroon, P. (1974b). Metabolism 23, 425.

Katyare, S. \& Howland, J. (1974). FEBS Lett. 43, 17.

Kornacker, M. \& Lowenstein, J. (1964). Science, N.Y. 144, 1027.

Koschinsky, T., Gries, F. \& Herberg, L. (1971). Diabetologia 7, 316.

Knittle, J. \& Hirsch, J. (1968). F. clin. Invest. 47, 2091.

Loten, E., Rabinovitch, A. \& Jeanrenaud, B. (1974). Diabetologia 10, 45.

Marshall, N. \& Engel, F. (1960). J. Lipid Res. 1, 339.

Muto, Y. \& Gibson, D. (1970). Biochem. biophys. Res. Commun. 38, 9.

Nakanishi, S. \& Numa, S. (1971). Proc. natn. Acad. Sci. U.S.A. 68, 2288.

Pullar, J. \& Webster, A. (1974). Br. F. Nutr. 3r, 377.

Rath, E., Hems, D. \& Beloff-Chain, A. (1974). Diabetologia 10, 261.

Salans, L., Cushman, S., Horton, E., Danforth, E. \& Sims, E. (1974). In Obesity, p. 204 [W. Burland, P. Samuel and J. Yudkin, editors]. Edinburgh: Churchill Livingstone.

Salmon, M. \& Hems, D. (1973). Biochem. $\mathcal{~}$. 136, 55 I.

Schonfeld, G., Felski, C. \& Howald, M. (1974). \%. Lipid Res. 15, 457.

Schonfeld, G. \& Pfleger, B. (1971). Am. F. Physiol. 220, 1178.

Stauffacher, W. \& Renold, A. (1969). Am. F. Physiol. 216, 98.

Steinmetz, J., Lowry, L. \& Yen, T. (I969). Diabetologia 5, 373.

Takemoto, S., Ishikawa, E. \& Iwatsuka, H. (1975). Horm. metab. Res. 7, 242.

Treble, D. \& Mayer, J. (1963). Nature, Lond. 200, 363.

Tsuji, S. \& Meier, H. (1970). Biochim. biophys. Acta $210,420$.

Wahle, K. W. J. (1974). Comp. Biochem. Physiol. 48B, 565 .

York, D. (1975). Nutr. Rep. int. 11, 379.

York, D. \& Bray, G. (I973a). Metabolism 22, 443.

York, D. \& Bray, G. (I973b). Horm. metab. Res. 5, 355.

Zucker, L. (1967). f. Nutr. 91, 247.

Zucker, L. (1972). F. Lipid Res. 13, 324.

Zucker, L. \& Antoniades, H. (1972). Endocrinology 90, 1320. 